\title{
Modelowanie bilansu węgla organicznego w glebie oraz emisji gazów cieplarnianych w skali regionalnej oraz w Polsce ${ }^{3}$
}

\section{Modeling of Soil Organic Carbon Balance and Greenhouse Gas Emissions on a Regional Scale and in Poland}

\begin{abstract}
Synopsis. Celem pracy były symulacje uproszczonego bilansu węgla oraz pochłaniania i emisji gazów cieplarnianych $\left(\mathrm{CO}_{2}, \mathrm{CH}_{4}, \mathrm{~N}_{2} \mathrm{O}\right)$ dla scharakteryzowania potencjału mitygacji zmian klimatu w rolniczym użytkowaniu gruntów ornych. Symulacje wykonywano przy użyciu modelu DNDC dla województw i Polski z użyciem dwudziestoletnich serii danych meteorologicznych. Stwierdzono, że system uprawy płużnej ze zbiorem resztek pożniwnych (a) powodować będzie w Polsce emisję netto tych gazów wynoszącą $0,203 \mathrm{t} \mathrm{CO}_{2} \mathrm{ekw} \cdot \mathrm{ha}^{-1} \cdot \mathrm{r}^{-1}$. Natomiast system uprawy uproszczonej z pozostawieniem na polu resztek pożniwnych (b) oraz system uprawy płużnej z regularnym stosowaniem obornika i zbiorem resztek pożniwnych (c) pochłaniać będą $\mathrm{CO}_{2}$ w ilościach wynoszących odpowiednio: 1,225 i $0,172 \mathrm{t} \mathrm{CO}_{2}$ ekw. $\cdot \mathrm{ha}^{-1} \cdot \mathrm{r}^{-1}$. Uzyskane wyniki sugerują, że $\mathrm{w}$ perspektywie średnioterminowej (20 lat), badane systemy uprawy mogą być uznane za praktyki mitygujące zmiany klimatu. Zastosowanie systemów uprawy w pożądanej proporcji w stosunku do areału gruntów ornych w Polsce mogłoby pozwolić na średnie pochłanianie gazów cieplarnianych rzędu $0,556 \mathrm{t} \mathrm{CO}_{2} \mathrm{ekw} \cdot \mathrm{ha}^{-1} \cdot \mathrm{r}^{-1}$
\end{abstract}

Slowa kluczowe: gleba, węgiel organiczny, sekwestracja, gazy cieplarniane

\begin{abstract}
The aim of the work was simulations of soil organic carbon balances as well as absorption and emission of greenhouse gases $\left(\mathrm{CO}_{2}, \mathrm{CH}_{4}, \mathrm{~N}_{2} \mathrm{O}\right)$ to characterize the mitigation potential of climate change in agricultural use of arable land. Simulations were performed using the DNDC model for voivodships and Poland using a twenty-year series of meteorological data. It was found that the plow cultivation system with the harvest residue (a) will cause in Poland a net emission of these gases amounting to $0.203 \mathrm{t} \mathrm{CO}$ eq $\cdot \mathrm{ha}^{-1} \cdot \mathrm{y}^{-1}$. On the other hand, the reduced tillage system leaving crop residues on the field (b) and the tillage system with the regular application of manure and harvest residues (c) will absorb $\mathrm{CO}_{2}$ in amounts: 1.225 and $0.172 \mathrm{t} \mathrm{CO}_{2} \mathrm{eq} \cdot \mathrm{ha}^{-1} \cdot \mathrm{y}^{-1}$ respectively. The obtained results suggest that in the medium-term (20 years) the studied cultivation systems may be recognized as practices mitigating climate change. The use of cultivation systems in the desired proportion in relation to the area of arable land in Poland could give an average greenhouse gas absorption of 0.556 $\mathrm{t} \mathrm{CO}_{2} \mathrm{eq} \cdot \mathrm{ha}^{-1} \cdot \mathrm{y}^{-1}$
\end{abstract}

Key words: soil, organic carbon, sequestration, greenhouse gases

JEL Classification: Q15, Q54

\footnotetext{
${ }^{1}$ prof. dr hab., IUNG-PIB, ul. Czartoryskich 8, 24-100 Puławy, e-mail: faber@iung.pulawy.pl; https://orcid.org/0000-0002-3055-1968

${ }^{2}$ dr, IUNG-PIB, ul. Czartoryskich 8, 24-100 Puławy, e-mail: zjarosz@iung.pulawy.pl; https://orcid.org/0000-0002-3428-5804

${ }^{3}$ Opracowanie wykonano w ramach zadania $2.6 \mathrm{w}$ programie wieloletnim IUNG-PIB.
} 


\section{Wprowadzenie}

W październiku 2014 r. Rada Europy zatwierdziła porozumienie w sprawie ram polityki klimatyczno-energetycznej do roku 2030, zgodnie z którym emisje gazów cieplarnianych (GHG) powinny zostać ograniczone o co najmniej 40\% w stosunku do 1990 r. (Komisja Europejska, 2016). Dla sektorów nie objętych handlem emisjami (w tym rolnictwa) ustalono redukcję emisji na poziomie $30 \% \mathrm{w}$ porównaniu do roku 2005. Jest to znaczący wzrost w stosunku do celu $-10 \%$ w 2020 r., skłaniający do wdrażania aktywności ograniczających emisję GHG poprzez zwiększenie sekwestracji węgla organicznego w glebach.

Wegiel organiczny (C), wchodzacy w skład glebowej materii organicznej (MO), kształtuje istotne funkcje gleb, miedzy innymi takie jak: przemiany składników pokarmowych, struktura, pojemność wodna, aktywność mikroorganizmów glebowych, co wpływa na ich produkcyjność (Merante i in., 2014). Wzrost zawartości C w glebie (sekwestracja C) jest wiec pożądany ze względu na poprawę fizycznych i chemicznych właściwości gleb oraz ich funkcji (Krawczynski i in., 2015).

Zasoby $\mathrm{C}$ w glebach intensywnie użytkowanych rolniczo mają tendencję do obniżania się (Freibauer i in., 2004; Merante $\mathrm{i}$ in., 2014). Powoduje to nie tylko pogorszenie funkcjonowania gleb, ale może prowadzić również do wymiernych strat $\mathrm{w}$ plonowaniu roślin (Merante i in., 2014). Ujemny bilans węgla w niektórych regionach UE (Merante i in., 2014) przyczynia się przy tym do wzrostu emisji dwutlenku wegla $\left(\mathrm{CO}_{2}\right)$, pogarszając bilans emisji gazów cieplarnianych z użytkowania gruntów rolnych. Mimo to uważa się, że rolnictwo ma duży - niewykorzystany dotychczas w wystarczającym stopniu - potencjał sekwestracji C, jeśli prowadzone będą odpowiednie praktyki sprzyjające temu procesowi (Kane, 2015; Lugato i in., 2015; Wiśniewski i Kistowski, 2017; Verschuuren, 2018).

Gleby w Polsce charakteryzują się dość niską zawartością węgla organicznego w warstwie ornej, znajdującą się w granicach od 0,3 do 5,8\% (średnio 1,2\%) (Stuczyński $\mathrm{i}$ in., 2007). Zawartości C mniejsze niż $1 \%$ stwierdzono w Polsce w $42 \%$ badanych próbek glebowych. Przyjmuje się, że taka zawartość C pogarsza rolnicze właściwości i produkcyjność gleb. Straty plonów na tych glebach w Polsce mogą wynosić 5-20\%. Gleby o zawartości C poniżej 2\% stanowią 92\% ogółu badanych próbek gleb w Polsce (Merante i in., 2014). Gleby te mogą charakteryzować się pogorszoną wartością użytkową. Dążenie do zwiększenia zawartości $\mathrm{C}$ w glebach w Polsce niezbędne jest więc nie tylko ze względu na ochronę klimatu, ale również ze względów produkcyjnych.

Jednym $\mathrm{z}$ podstawowych sposobów zwiększenia sekwestracji $\mathrm{C}$ organicznego w glebach jest zastąpienie orki uprawą uproszczoną (płytka uprawa bez odwracania skiby), co zmniejsza natlenienie gleb i ogranicza mineralizację MO. Jeśli przy tym zwiększy się dopływ węgla do gleb, np. pozostawiając na polu $100 \%$ resztek pożniwnych, można spodziewać się poprawy bilansu węgla $\mathrm{w}$ glebie (ECCP, 2003). Stosowanie tej praktyki nieprzerwanie przez wiele lat sprawić może, że proces sekwestracji C zachodzić będzie do ustalenia się nowej równowagi w glebie, co osiagnięte będzie po około 20-30 latach (Krasuska i in., 2016; Lugato i in., 2018; West i Six, 2007). Węgiel przy takim systemie uprawy tym trwalej wiązany będzie $w$ glebach, im więcej zawierać one będą iłu koloidalnego (Merante i in., 2014). Innym sposobem zwiększenia sekwestracji C, od dawna praktykowanym, jest regularne stosowanie obornika.

System uprawy uproszczonej z pozostawieniem na polu od 30 do $70 \%$ resztek pożniwnych (uprawa konserwująca) należałoby zalecać gospodarstwom bezinwentarzowym, aby uzyskać szereg korzyści ekologicznych, w tym nie dopuścić do obniżania się zasobów C 
(Basch i in., 2017; Searle i Bitnere, 2017; Ranaivoson i in., 2017). Szacuje się, że system ten stosowany jest w UE27 na średnio $26 \%$ areału gruntów ornych. W takich krajach jak Cypr, Bułgaria czy Niemcy system ten jest prowadzony na ponad $40 \%$ areału gruntów ornych (Kertész i Madarász, 2014). W Polsce nie jest on tak popularny. W gospodarstwach, które dysponują obornikiem, regularne jego stosowanie w zmianowaniu może wystarczyć do zbilansowania przemian węgla w glebie (Bieńkowski i Jankowiak, 2006).

Węgiel organiczny wniesiony do gleb z resztkami pożniwnymi lub obornikiem ulega cyklicznym przemianom związanym z przemianami azotu. W zależności od stosunku C:N ulega on w $80-95 \%$ mineralizacji w okresie krótszym niż 5 lat, w wyniku czego uwalniane są mineralne składniki pokarmowe oraz $\mathrm{CO}_{2}$ do atmosfery. Pozostała część $\mathrm{C}$ jest humifikowana i trwale wiązana co sprawia, że węgiel taki przebywa $\mathrm{w}$ glebie nawet przez okres do 100 lat (Dignac i in., 2017). Ze względu na ochronę klimatu, istotnym elementem $\mathrm{w}$ rozwoju rolnictwa winno więc być zwiększanie zawartości $\mathrm{C}$ organicznego trwale związanego w glebie.

Faber, Jarosz (2018) wykazali że systemy uprawy zwiększające sekwestrację C w glebie zwiększają emisję bezpośrednią i pośrednią podtlenku azotu. W prezentowanej pracy analizuje się czy wzrost ten jest kompensowany przez sekwestrację węgla organicznego. Analizie poddano bilanse węgla organicznego oraz bilanse emisji dwutlenku węgla $\left(\mathrm{CO}_{2}\right)$, metanu $\left(\mathrm{CH}_{4}\right)$ i podtlenku azotu $\left(\mathrm{N}_{2} \mathrm{O}\right)$.

Celem opracowania było przedstawienie uproszczonego bilansu węgla oraz pochłaniania $\mathrm{i}$ emisji gazów cieplarnianych $\left(\mathrm{CO}_{2}, \mathrm{CH}_{4}, \mathrm{~N}_{2} \mathrm{O}\right)$ w poszczególnych województwach i w Polsce dla scharakteryzowania potencjału mitygacji zmian klimatu w rolniczym użytkowaniu gruntów ornych.

\section{Materiał i metody}

W badaniach wykorzystano model DNDC (wersja 9.2) (Giltrap i in., 2010) w kalibracji opracowanej w JRC EC dla Europy (Leip i in., 2008). Model ten ma bogate referencje i wykorzystywany był $\mathrm{w}$ wielu miejscach na świecie do symulacji bilansów węgla, azotu i wody, emisji $\mathrm{CH}_{4} \mathrm{i} \mathrm{N}_{2} \mathrm{O}$ oraz sekwestracji węgla organicznego w glebach pod uprawami rolniczymi (na poziomie pola) (DNDC). Przed zastosowaniem model był rekalibrowany w IUNG-PIB.

Symulacje wykonywano z uwzględnieniem kategorii agronomicznych gleb ciężkich, średnich, lekkich oraz bardzo lekkich dla systemów uprawy: (a) płużnej z mineralnym nawożeniem azotem i zbiorem resztek pożniwnych, który był traktowany jako referencyjny dla dwóch kolejnych systemów zwiększających sekwestrację węgla, (b) uproszczonej $\mathrm{z}$ mineralnym nawożeniem azotem oraz pozostawieniem $100 \%$ resztek pożniwnych na polu oraz (c) płużnej z mineralnym nawożeniem azotem i stosowaniem obornika $\left(170 \mathrm{~kg} \cdot \mathrm{N} \mathrm{ha}^{-1}\right.$ raz w zmianowaniu roślin) oraz zbiorem resztek pożniwnych. Badane systemy uprawy charakteryzują uprawę: a) w gospodarstwach bezinwentarzowych, b) w gospodarstwach bezinwentarzowych, stosujących uprawę konserwująca oraz c) w gospodarstwach posiadających inwentarz i stosujących obornik. Na uwzględnionych w badaniach glebach symulowano uprawę rośliny odpowiednio dobranych do ich właściwości w zmianowaniach dostostosowanych do struktury zasiewów w województwach. Rośliny nawożone były azotem według zaleceń nawozowych. 
Ogółem wykonano 3840 rocznych symulacji (20 lat x 4 kategorie gleb x 3 systemy uprawy x 16 województw). Symulowanymi charakterystykami były: plon produktu głównego $\left(\mathrm{t} \mathrm{C} \cdot \mathrm{ha}^{-1} \cdot \mathrm{r}^{-1}\right)$, emisje metanu $\left(\mathrm{kg} \mathrm{C} \cdot \mathrm{ha}^{-1} \cdot \mathrm{r}^{-1}\right)$, sekwestracja węgla organicznego w glebach i systemach uprawy $\left(\mathrm{t} \mathrm{C} \cdot \mathrm{ha}^{-1} \cdot \mathrm{r}^{-1}\right)$ oraz bilans emisji $\mathrm{CO}_{2}, \mathrm{CH}_{4}$ i N $\mathrm{N}_{2} \mathrm{O}$. Opis eksperymentów symulacyjnych wykonanych dla okresu 20-lecia oraz wielkości symulowanych emisji podtlenku azotu przedstawiono we wcześniejszej publikacji (Faber i Jarosz, 2018). Wyniki zestawiono dla województw oraz Polski. Średnie ważone symulowane charakterystyki dla systemów uprawy w Polsce obliczono zakładając procentowe udziały systemów: (a) $10 \%$, (b) $40 \%$ oraz (c) $50 \%$.

Emisje $\mathrm{CO}_{2}, \mathrm{CH}_{4}$ oraz $\mathrm{N}_{2} \mathrm{O}$ przeliczono na równoważniki (ekwiwalent) $\mathrm{CO}_{2}$, stosując współczynniki globalnego ocieplenia dla okresu 100-lecia, które wynoszą odpowiednio: 1, 25 i 298 (IPCC, 2007).

\section{Wyniki badań}

Plony węgla produktu głównego uprawianych roślin były zróżnicowane w poszczególnych województwach, zarówno w obrębie systemu uprawy, jak również pomiędzy systemami uprawy (tab. 1).

Tabela. 1. Plon produktu głównego w wybranych systemach uprawy ( $\left.\mathrm{t} \mathrm{C} \mathrm{ha}^{-1} \mathrm{r}^{-1}\right)$

Table 1. Main product yield in selected cultivation systems $\left(\mathrm{t} \mathrm{Cha}^{-1} \mathrm{y}^{-1}\right)$

\begin{tabular}{|c|c|c|c|c|}
\hline \multirow{2}{*}{ Województwo } & \multicolumn{3}{|c|}{ Uprawa } & \multirow{2}{*}{ Średnia } \\
\hline & $\mathrm{a}$ & $\mathrm{b}$ & $\mathrm{c}$ & \\
\hline Dolnośląskie & 1,300 & 1,032 & 1,340 & 1,213 \\
\hline Kujawsko-pomorskie & 2,124 & 2,017 & 2,321 & 2,180 \\
\hline Lubelskie & 1,876 & 1,590 & 2,051 & 1,849 \\
\hline Lubuskie & 2,311 & 2,484 & 2,729 & 2,589 \\
\hline Łódzkie & 2,555 & 2,620 & 2,887 & 2,747 \\
\hline Małopolskie & 1,293 & 1,098 & 1,432 & 1,285 \\
\hline Mazowieckie & 2,296 & 2,473 & 2,665 & 2,551 \\
\hline Opolskie & 1,563 & 1,341 & 1,769 & 1,577 \\
\hline Podkarpackie & 1,921 & 1,649 & 2,299 & 2,001 \\
\hline Podlaskie & 2,244 & 2,315 & 2,525 & 2,413 \\
\hline Pomorskie & 2,090 & 2,151 & 2,394 & 2,266 \\
\hline Śląskie & 1,939 & 1,910 & 2,122 & 2,019 \\
\hline Świętokrzyskie & 2,298 & 2,188 & 2,581 & 2,396 \\
\hline Warmińsko-mazurskie & 2,222 & 2,331 & 2,482 & 2,396 \\
\hline Wielkopolskie & 2,334 & 2,445 & 2,722 & 2,572 \\
\hline Zachodniopomorskie & 2,247 & 2,436 & 2,566 & 2,482 \\
\hline Polska & 2,079 & 2,104 & 2,370 & 2,234 \\
\hline
\end{tabular}

Źródło: obliczenia własne. 
Pozostawienie na polu całej ilości resztek pożniwnych (b) zmniejszało plon w stosunku do systemu uprawy (a) w ośmiu województwach średnio o $11 \%$ i zwiększało plon w pozostałych województwach średnio o 5\%. W Polsce system ten zwiększał plon o $1 \%$. Przyczyną spadku symulowanych plonów w niektórych województwach były ograniczenia w pobieraniu azotu (Faber i Jarosz, 2018). W Europie ograniczenie orki w zmianowaniu zmniejszało plony od 0 do 10\% (Soane i in., 2013; van den Putte i in., 2010). Stosowanie obornika (c) zwiększało plony w stosunku do (a) i (b). Gdyby udział systemów uprawy odpowiadał założonemu $\mathrm{w}$ pracy, to plony $\mathrm{w}$ Polsce wzrosłyby o $7 \% \mathrm{w}$ stosunku do systemu (a). Warunki, w których uproszczenia uprawy nie powodują strat plonów zostały wstępnie rozpoznane (Pittelkow i in., 2015). W Polsce większy wpływ na redukcję plonów miało następstwo roślin niż ograniczanie orki (Jaskulska i in., 2013).

Symulowane emisje metanu były w badanych systemach uprawy ujemne, co oznacza, że gleby pochłaniały ten gaz (tab. 2). Jest to sytuacja typowa dla gleb mineralnych o uregulowanych stosunkach powietrzno-wodnych. W takich warunkach w glebie przeważają procesy mikrobiologicznego utleniania $\mathrm{CH}_{4}$ nad jego powstawaniem wskutek metanogenezy (Bayer i in., 2012; Le Mer i Roger, 2001). Tylko grunty zalewane i podmokłe mogą emitować metan do atmosfery (Le Mer i Roger, 2001).

Tabela 2. Emisja metanu w systemach uprawy $\left(\mathrm{kg} \mathrm{C} \mathrm{ha}^{-1} \mathrm{r}^{-1}\right)$

Table 2. Methane emission in cultivation systems $\left(\mathrm{kg} \mathrm{Cha}^{-1} \mathrm{y}^{-1}\right)$

\begin{tabular}{lcccc}
\hline \multirow{2}{*}{ Województwo } & & Uprawa & \multirow{2}{*}{ Średnia } \\
\cline { 2 - 4 } Dolnośląskie & $\mathrm{a}$ & $\mathrm{b}$ & $\mathrm{c}$ & $-0,245$ \\
Kujawsko-pomorskie & $-0,203$ & $-0,253$ & $-0,248$ & $-0,395$ \\
Lubelskie & $-0,337$ & $-0,402$ & $-0,402$ & $-0,408$ \\
Lubuskie & $-0,339$ & $-0,445$ & $-0,392$ & $-0,198$ \\
Lódzkie & $-0,020$ & $-0,457$ & $-0,027$ & $-0,425$ \\
Małopolskie & $-0,388$ & $-0,462$ & $-0,404$ & $-0,108$ \\
Mazowieckie & $-0,199$ & $-0,117$ & $-0,083$ & $-0,351$ \\
Opolskie & $-0,301$ & $-0,405$ & $-0,318$ & $-0,266$ \\
Podkarpackie & $-0,203$ & $-0,282$ & $-0,265$ & $-0,339$ \\
Podlaskie & $-0,300$ & $-0,352$ & $-0,337$ & $-0,365$ \\
Pomorskie & $-0,315$ & $-0,382$ & $-0,361$ & $-0,382$ \\
Śląskie & $-0,360$ & $-0,360$ & $-0,404$ & $-0,284$ \\
Świętokrzyskie & $-0,259$ & $-0,264$ & $-0,305$ & $-0,327$ \\
Warmińsko-mazurskie & $-0,268$ & $-0,350$ & $-0,320$ & $-0,256$ \\
Wielkopolskie & $-0,334$ & $-0,087$ & $-0,377$ & $-0,425$ \\
Zachodniopomorskie & $-0,372$ & $-0,451$ & $-0,414$ & $-0,430$ \\
Polska & $-0,376$ & $-0,464$ & $-0,413$ & $-0,351$ \\
\hline
\end{tabular}

Źródło: obliczenia własne.

Materia organiczna wnoszona do gleby podlega cyklicznym przemianom rozkładu, czego efektami są utrata węgla organicznego w postaci $\mathrm{CO}_{2}$ emitowanego do atmosfery (znak minus) lub jego sekwestracji (znak plus). O przebiegu tych procesów decyduja 
czynniki biotyczne (roślinność, fauna i mikroorganizmy glebowe) oraz czynniki abiotyczne (klimat, zasoby węgla w glebie, użytkowanie gruntów, właściwości fizyko-chemiczne gleb, stosunek C:N) (Dignac i in., 2017; Stockmann i in., 2013). W przeprowadzonych eksperymentach symulacyjnych w systemie uprawy płużnej (a) węgiel traciły gleby ciężkie i bardzo lekkie, natomiast sekwestrowały go gleby średnie i lekkie (tab. 3). W systemach uprawy (b) i (c) węgiel był sekwestrowany na wszystkich glebach, z tym jednakże, iż na glebach bardzo lekkich ilości sekwestrowanego $\mathrm{C}$ były znacząco mniejsze. Przeprowadzone badania potwierdzają ustalenia poparte wieloletnimi doświadczeniami, w których stwierdzono znikomą sekwestrację lub nawet jej brak na glebach piaszczystych (Poeplau i in., 2015).

Tabela 3. Mediana (Me) i medianowe odchylenie od median (MAD) sekwestracji węgla organicznego $\left(\mathrm{t} \mathrm{C} \cdot \mathrm{ha}^{-1}\right.$. $\mathrm{r}^{-1}$ ) dla systemów uprawy stosowanych w czterech kategoriach agronomicznych gleb

Table 3. Median (Me) and median absolute deviation (MAD) of organic carbon sequestration $\left(\mathrm{t} \mathrm{C} \cdot \mathrm{ha}^{-1} \cdot \mathrm{y}^{-1}\right)$ for cultivation systems used in four agronomic soil categories

\begin{tabular}{cccccc}
\hline \multirow{2}{*}{ System uprawy } & Statystyka & \multicolumn{3}{c}{ Gleby } \\
\cline { 3 - 6 } & & ciężkie & średnie & lekkie & bardzo lekkie \\
\hline \multirow{2}{*}{$\mathrm{a}$} & Me & $-0,024$ & 0,020 & 0,017 & $-0,042$ \\
& MAD & 0,086 & 0,058 & 0,062 & 0,046 \\
$\mathrm{~b}$ & Me & 0,557 & 0,641 & 0,498 & 0,234 \\
& MAD & 0,148 & 0,078 & 0,088 & 0,154 \\
$\mathrm{c}$ & Me & 0,281 & 0,192 & 0,289 & 0,147 \\
& MAD & 0,078 & 0,057 & 0,061 & 0,123 \\
\hline
\end{tabular}

Źródło: obliczenia własne.

W systemie uprawy (a) straty węgla odnotowano w dziesięciu województwach, zaś w pozostałych zachodziła niewielka sekwestracja (tab. 4). W skali Polski w tym systemie uprawy straty węgla były na tyle małe, iż można uznać, że bilans $\mathrm{C}$ był niemal zrównoważony. Wynik ten jest zgodny $\mathrm{z}$ danymi $\mathrm{z}$ monitoringu zawartości węgla $\mathrm{w}$ glebach Polski (Faber i in., 2015). W UE15 straty C przy obecnie stosowanej agrotechnice wynosily $0,1-0,5 \mathrm{tC} \cdot \mathrm{ha}^{-1} \cdot \mathrm{r}^{-1}$ (Leip i in., 2008).

W systemie uprawy (b) ilości sekwestrowanego $\mathrm{C}$ wahały się w granicach od 0,277 do 0,761 , przy medianie dla Polski wynoszącej $0,533 \mathrm{t} \mathrm{C} \cdot \mathrm{ha}^{-1} \cdot \mathrm{r}^{-1}$. Sekwestracje w systemie (c) wynosiły natomiast od 0,107 do 0,310 , przy medianie dla Polski wynoszącej 0,230 t C . $\mathrm{ha}^{-1} \cdot \mathrm{r}^{-1}$. Zastosowanie systemów w Polsce według przyjętych udziałów systemów uprawy dawałoby medianę sekwestracji $0,322 \mathrm{t} \mathrm{C} \cdot \mathrm{ha}^{-1} \cdot \mathrm{r}^{-1}$. W krajach UE15 potencjały sekwestracji C wynoszą ( $\left.\mathrm{w} \mathrm{t} \mathrm{C} \cdot \mathrm{ha}^{-1} \cdot \mathrm{r}^{-1}\right)$ : w systemach $\mathrm{z}$ ograniczoną orką $<0,4$ (niepewność $\geq 50 \%$ ); pozostawienie na polu resztek pożniwnych 0,2-0,7 (niepewność $>50 \%$ ) oraz stosowanie obornika 0,4-1,5 (niepewność $>50 \%$ ) (Freibauer i in., 2004). Stwierdzona sekwestracja $C$ wskutek stosowania obornika wahała się w granicach 0,20 $0,50 \mathrm{t} \mathrm{C} \cdot \mathrm{ha}^{-1} \cdot \mathrm{r}^{-1}$ (Peltre i in., 2012). Uzyskane w badaniach własnych wyniki mieściłyby się w zakresach sekwestracji podawanych w cytowanej literaturze. Sekwestracje mniejsze $\left(0,16-0,31 \mathrm{t} \mathrm{C} \cdot \mathrm{ha}^{-1} \cdot \mathrm{r}^{-1}\right)$ stwierdzono dla systemu uprawy uproszczonej z pozostawieniem resztek pożniwnych według symulacji z użyciem modelu CENTURY (Lugato i in., 2015). 
Tabela 4. Sekwestracja węgla organicznego w glebie w wybranych systemach uprawy $\left(\mathrm{t} \mathrm{C} \cdot \mathrm{ha}^{-1} \cdot \mathrm{r}^{-1}\right)$

Table 4. Sequestration of organic carbon in soil in selected cultivation systems $\left(\mathrm{t} \mathrm{C} \cdot \mathrm{ha}^{-1} \cdot \mathrm{y}^{-1}\right)$

\begin{tabular}{lcccc}
\hline \multirow{2}{*}{ Województwo } & \multicolumn{2}{c}{ Uprawa } & Średnia \\
\cline { 2 - 4 } Dolnośląskie & $\mathrm{a}$ & $\mathrm{b}$ & 0,107 & 0,139 \\
Kujawsko-pomorskie & $-0,051$ & 0,277 & 0,306 & 0,290 \\
Lubelskie & 0,024 & 0,337 & 0,182 & 0,269 \\
Lubuskie & $-0,033$ & 0,451 & 0,127 & 0,256 \\
Lódzkie & $-0,069$ & 0,499 & 0,310 & 0,419 \\
Małopolskie & 0,139 & 0,626 & 0,277 & 0,287 \\
Mazowieckie & $-0,002$ & 0,434 & 0,281 & 0,453 \\
Opolskie & 0,079 & 0,761 & 0,265 & 0,303 \\
Podkarpackie & $-0,001$ & 0,472 & 0,174 & 0,204 \\
Podlaskie & $-0,044$ & 0,304 & 0,195 & 0,299 \\
Pomorskie & 0,003 & 0,503 & 0,203 & 0,304 \\
Śląskie & $-0,049$ & 0,518 & 0,168 & 0,282 \\
Świętokrzyskie & $-0,012$ & 0,498 & 0,287 & 0,378 \\
Warmińsko-mazurskie & 0,107 & 0,560 & 0,239 & 0,362 \\
Wielkopolskie & 0,027 & 0,598 & 0,250 & 0,347 \\
Zachodniopomorskie & $-0,016$ & 0,558 & 0,227 & 0,305 \\
Polska & $-0,036$ & 0,489 & 0,533 & \\
\hline
\end{tabular}

Źródło: obliczenia własne.

Bilans pochłaniania $\mathrm{i}$ emisji $\mathrm{CO}_{2}, \mathrm{CH}_{4}$ oraz emisji $\mathrm{N}_{2} \mathrm{O}$ był dodatni w 15 województwach w systemie uprawy (a), co oznacza, że system uprawy płużnej ze zbiorem resztek pożniwnych przyczyniał się do ocieplenia klimatu (tab. 5). Jest to efekt zbyt małej sekwestracji węgla dla zrównoważenia emisji $\mathrm{N}_{2} \mathrm{O}$ (Faber i Jarosz, 2018). We wszystkich województwach, $\mathrm{z}$ wyjątkiem dolnośląskiego, w systemach (b) i (c) przeważało pochłanianie gazów cieplarnianych (znak ujemny). W skali Polski mediana pochłaniania w systemie (b) wynosiła -1,225, zaś w systemie (c) - 0, 172 t $\mathrm{CO}_{2} \mathrm{ekw} \cdot \cdot \mathrm{ha}^{-1} \cdot \mathrm{r}^{-1}$. Gdyby systemy uprawy stosowano według założonych udziałów, mediana pochłaniania gazów cieplarnianych wynosiłaby w Polsce $-0,556 \mathrm{t} \mathrm{CO}_{2} \mathrm{ekw} \cdot \mathrm{ha}^{-1} \cdot \mathrm{r}^{-1}$.

Zgodnie $\mathrm{z}$ przyjętą kategoryzacją klimatu Polska leży w strefie klimatu umiarkowanego chłodnego i suchego (pas Wielkich Dolin) oraz umiarkowanego chłodnego i wilgotnego (niektóre województwa na północy i południu kraju) (Krasuska i in., 2016). Zastosowanie uprawy uproszczonej i pozostawienie na polu resztek pożniwnych zapewniało w strefie pierwszej, według literatury, pochłanianie emisji wynoszące średnio $0,17 \mathrm{CO}_{2} \mathrm{ekw} \cdot \mathrm{ha}^{-1} \cdot \mathrm{r}^{-1}$ (95\% przedział ufności od emisji 0,52 do pochłaniania 0,86$)$, zaś w drugiej strefie klimatycznej średnio $0,53 \mathrm{CO}_{2} \mathrm{ekw} \cdot \cdot \mathrm{ha}^{-1} \cdot \mathrm{r}^{-1}(95 \%$ przedział ufności od 0,04 do 1,12) (Smith i in., 2008). Uzyskane wyniki w badaniach własnych mieszczą się w górnych zakresach przedziałów określonych w cytowanej literaturze, co wynikać może z niskiej zawartości C w naszych glebach, warunkującej wysokie potencjały sekwestracji. 
Tabela 5. Bilans emisji dwutlenku węgla, podtlenku azotu oraz metanu w wybranych systemach uprawy $\left(\mathrm{w}^{\mathrm{t}} \mathrm{CO}_{2}\right.$ $\left.\mathrm{ekw} \cdot \mathrm{ha}^{-1} \cdot \mathrm{r}^{-1}\right)$

Table 5. Balance of carbon dioxide, nitrous oxide and methane emissions in selected cultivation systems (in $\mathrm{t} \mathrm{CO}_{2}$ eq $\left.\cdot \mathrm{ha}^{-1} \cdot \mathrm{y}^{-1}\right)$

\begin{tabular}{lcccc}
\hline \multirow{2}{*}{ Województwo } & \multicolumn{1}{c}{ Uprawa } & \multirow{2}{*}{ Średnia } \\
\cline { 2 - 4 } & $\mathrm{a}$ & $\mathrm{b}$ & $\mathrm{c}$ & 0,651 \\
\cline { 2 - 4 } Dolnośląskie & 0,597 & 0,533 & 0,755 & $-0,375$ \\
Kujawsko-pomorskie & 0,103 & $-0,530$ & $-0,347$ & $-0,047$ \\
Lubelskie & 0,373 & $-0,530$ & 0,254 & $-0,433$ \\
Lubuskie & 0,429 & $-1,175$ & $-0,011$ & $-1,143$ \\
Lódzkie & $-0,354$ & $-1,762$ & $-0,805$ & $-0,257$ \\
Małopolskie & 0,269 & $-0,630$ & $-0,063$ & $-1,342$ \\
Mazowieckie & 0,154 & $-2,494$ & $-0,720$ & $-0,276$ \\
Opolskie & 0,233 & $-0,608$ & $-0,122$ & $-0,103$ \\
Podkarpackie & 0,361 & $-0,331$ & $-0,014$ & $-0,362$ \\
Podlaskie & 0,336 & $-0,843$ & $-0,122$ & $-0,721$ \\
Pomorskie & 0,331 & $-1,443$ & $-0,355$ & $-0,303$ \\
Śląskie & 0,296 & $-0,703$ & $-0,103$ & $-0,869$ \\
Świętokrzyskie & 0,002 & $-1,335$ & $-0,671$ & $-0,836$ \\
Warmińsko-mazurskie & 0,121 & $-1,578$ & $-0,434$ & $-0,826$ \\
Wielkopolskie & 0,202 & $-1,564$ & $-0,422$ & $-0,584$ \\
Zachodniopomorskie & 0,308 & $-1,310$ & $-0,181$ & $-0,556$ \\
Polska & 0,203 & $-1,225$ & $-0,172$ & \\
\hline
\end{tabular}

Źródło: obliczenia własne

Bilanse węgla oraz pochłaniania i emisji obarczone są zazwyczaj dużą niepewnością (Freibauer i in., 2004; Smith i in., 2008). Wynika to z faktu, że uzależnione są od wielu czynników biotycznych i abiotycznych. Stwierdzone w badaniach własnych zmienności wynosiły 50\% dla sekwestracji i strat węgla organicznego (tab. 6), co jest zgodne z danymi literaturowymi (Freibauer i in., 2004). Największe jednak zmienności odnotowano dla bilansu GHG, co pokrywa się z danymi eksperymentalnymi dla Europy (Smith i in., 2008).

Tabela 6. MAD w stosunku do median zmiennych charakteryzujących gospodarkę węglem w systemach uprawy w Polsce (\%)

Table 6. MAD in relation to median variables characterizing coal management in cultivation systems in Poland $(\%)$

\begin{tabular}{lccc}
\hline \multirow{2}{*}{ Zmienna } & \multicolumn{2}{c}{ Uprawa } & $\mathrm{c}$ \\
\cline { 2 - 4 } & $\mathrm{a}$ & $\mathrm{b}$ & 21 \\
\hline Plon & 18 & 31 & 24 \\
Emisja metanu & 30 & 26 & 50 \\
Sekwestracja węgla & $*$ & 40 & 132 \\
Bilans GHG & 139 & 119 & \\
\hline *Me $=-0.001 ;$ MAD $=0.068 \mathrm{t} \mathrm{C}^{-1} \cdot \mathrm{ha}^{-1}$ & & \\
Źródło: obliczenia własne. & &
\end{tabular}

Przedstawione w pracy wyniki sugerują, że w warunkach Polski praktyki sekwestrujące węgiel zapewnić mogą ujemny bilans emisji gazów cieplarnianych pomimo tego, iż jednocześnie powodować mogą wzrost emisji $\mathrm{N}_{2} \mathrm{O}$ w stosunku do systemu uprawy 
płużnej (Faber i Jarosz, 2018). Jednakże wzrost ten nie spowoduje znaczącego wzrostu współczynnika emisji $\mathrm{N}_{2} \mathrm{O}$ w stosunku do metody szacowania emisji zalecanej przez IPCC (Faber i Jarosz, 2018). Uzyskane wyniki wskazują bowiem, że przy prowadzeniu systemów uprawy na założonych areałach (a -10\%, b - 40\% oraz c - 50\%) współczynnik emisji $\mathrm{N}_{2} \mathrm{O}$ dla Polski wynosić będzie nie 1\% zastosowanego azotu jak przyjmuje IPCC, ale 1,03\% (Faber i Jarosz, 2018).

Rozległe symulacje wykonane w ostatnich latach dla UE pozwalają stwierdzić, że gleby w Europie mogą pochłaniać netto $\mathrm{CO}_{2}$, jeśli wprowadzać się będzie do nich większe ilości resztek pożniwnych i zmniejszy się intensywność orki (Lugato i in., 2018). Proces ten jednak będzie silnie powiązany $\mathrm{z}$ przemianami $\mathrm{N}$ w glebie. Ujemna emisja $\mathrm{CO}_{2}$ występować może bez wzrostu emisji $\mathrm{N}_{2} \mathrm{O}$ tylko do 2040 roku. Później sekwestracja C będzie minimalizowana przez wzrost emisji $\mathrm{N}_{2} \mathrm{O}$. W perspektywie roku 2060, w połowie punktów monitoringu $\mathrm{C}$ w glebach Europy (8000 punktów), występować będzie emisja netto $\mathrm{CO}_{2}$. Tak więc mitygacja zmian klimatu przez zwiększenie sekwestracji $\mathrm{C}$ w glebie zależeć będzie od praktyki nawożenia $\mathrm{N}$, co wpływa na emisje $\mathrm{N}_{2} \mathrm{O}$ i może być w przyszłości skuteczna przez okres co najwyżej 20-30 lat. Według innych badań zwiększenie sekwestracji $\mathrm{C}$ w glebie zwiększa tak znacznie emisje $\mathrm{N}_{2} \mathrm{O}$, że nie może w perspektywie długoterminowej być efektywną praktyką mitygacji zmian klimatu (Gu i in., 2017).

\section{Podsumowanie}

W pracy przedstawiono uproszczone bilanse węgla oraz pochłaniania i emisji gazów cieplarnianych $\left(\mathrm{CO}_{2}, \mathrm{CH}_{4}, \mathrm{~N}_{2} \mathrm{O}\right)$ w województwach i Polsce w okresie dwudziestolecia. Stwierdzono, że system uprawy płużnej ze zbiorem resztek pożniwnych powodować będzie w Polsce emisję netto tych gazów wynoszącą $0,203 \mathrm{t} \mathrm{CO}_{2} \mathrm{ekw} \cdot \mathrm{ha}^{-1} \cdot \mathrm{r}^{-1}$. Natomiast system uprawy uproszczonej z pozostawieniem na polu resztek pożniwnych oraz system uprawy płużnej z regularnym stosowaniem obornika i zbiorem resztek pożniwnych pochłaniać będą $\mathrm{CO}_{2} \mathrm{w}$ ilościach wynoszących odpowiednio:1,225 i 0,172 t $\mathrm{CO}_{2} \mathrm{ekw} \cdot \cdot \mathrm{ha}^{-1} \cdot \mathrm{r}^{-1}$. Uzyskane wyniki sugerują, że w perspektywie średnioterminowej (20-30 lat) badane systemy uprawy mogą być uznane za praktyki mitygujące zmiany klimatu. Zastosowanie systemów uprawy w pożądanej proporcji w stosunku do areału gruntów ornych w Polsce mogłoby pozwolić na średnie pochłanianie gazów cieplarnianych rzędu $0,556 \mathrm{t} \mathrm{CO}_{2} \mathrm{ekw} \cdot \cdot \mathrm{ha}^{-1} \cdot \mathrm{r}^{-1}$. Stwierdzone emisje i pochłaniania gazów cieplarnianych mieszczą się w zakresach danych podawanych w literaturze.

\section{Literatura}

Basch, G., González-Sánchez, E.J., Gil-Ribes, J., Ordóñez-Fernández, R.,Veroz-González, O., Triviño-Tarradas, P., Carbonell-Bojollo, R., Márquez-García, F., Gómez-Ariza, M., Holgado-Cabrera, A., Moreno-García, M. (2017). Mitigation of climate change through conservation agriculture in Europe. World Congress 7 on Conservation Agriculture. Rosary, Argentina, 1-4 August 2017, 67-71.

Bayer, C., Gomes, J., Vieira, F.C.B, Zanatta, J.A., Piccolo, M.C., Dieckow, J. (2012). Methane emission from soil under long-term no-till cropping systems. Soil and Tillage Research, 124, 1-7.

Bieńkowski, J., Jankowiak, J. (2006). Zawartość wegla organicznego w glebie i jego zmiany pod wpływem różnych systemów produkcji. (Organic carbon content in soils and its changes under the influence of different production systems). Fragmenta Agronomica, 2(90), 216-225. 
Dignac, M.F., Derrien, D., Barré, P., Barot, S., Cécillon, L., Chenu, C., Chevallier, T., Freschet, G.T., Garnier, P., Guenet, B., Hedde, M., Klumpp, K., Lashermes, G., Maron, P.A., Nunan, N., Roumet, C., Basile-Doelsch, I. (2017). Increasing soil carbon storage: mechanisms, effects of agricultural practices and proxies. A review. Agronomy for Sustainable Development, 37, 14. DOI:10.1007/s13593-017-0421-2.

ECCP (European Climate Change Programme). (2003). Working Group Sinks Related to Agricultural Soils Final Report. Pobrano kwietnia 2018 https://ec.europa.eu/clima/sites/clima/files/eccp/second/docs/finalreport_agricsoils en.pdf.

Faber, A., Jarosz, Z. (2018). Modelowanie bilansu azotu oraz emisji podtlenku azotu i amoniaku w skali regionalnej oraz Polsce. (Modeling of nitrogen balance and emission of nitrous oxide and ammonia on a regional scale and in Poland). ZN SGGW Problemy Rolnictwa Światowego, 18(2), 70-81.

Faber, A., Jarosz, Z., Łopatka, A., Siebielec, G. (2015). Ocena zmian zawartości węgla organicznego w glebach na podstawie danych monitoringu chemizmu gleb ornych w Polsce. (Assessment of changes in organic carbon content in soils based on monitoring data on arable soil chemistry in Poland). Studia i Raporty IUNG-PIB, $46(20), 9-20$.

Freibauer, A., Rounsevell, M. D. A., Smith, P., Verhagen, J. (2004). Carbon sequestration in the agricultural soils of Europe. Geoderma, 122, 1-23.

Giltrap, D. L., Li, C., Saggar, S. (2010). DNDC: A process-based model of greenhouse gas fluxes from agricultural soil. Agriculture, Ecosystems and Environment, 136, 292-300.

Gu, J., Yuan, M., Liu, J., Hao, Y., Zhou, Y., Qu, D., Yang, X. (2017). Trade-off between soil organic carbon sequestration and nitrous oxide emissions from winter wheat-summer maize rotations: Implications of a 25 year fertilization experiment in Northwestern China. Science of the Total Environment, 595, 371-379.

IPCC (2007). IPCC Fourth Assessment Report: Climate Change 2007. Contribution of Working Group I to the Fourth Assessment Report of the Intergovernmental Panel on Climate Change, 2007. 2.10.2 Direct Global Warming Potentials. Pobrano 11 kwietnia 2018 z: https://www.ipcc.ch/publications and data/ar4/ wg1/en/ch2s2-10-2.html\#table-2-14.

Jaskulska, I., Jaskulski, D., Kotwica, K., Wasilewski, P., Gałęzewski, L. (2013). Effect of tillage simplifications on yield and grain quality of winter wheat after different previous crops. Acta Scientarum Polonorum Agricultura, 12(3), 37-44

Kane, D. (2015). Carbon sequestration potential on agricultural lands: a review of current science and available practices. Breakthrough and strategies solution. National Sustainable Agriculture Coalition. pp. 35. Pobrano 5 kwietnia 2018 z: https://pdfs.semanticscholar.org/b89f/31b2d289b5b55f4a71cd3eeca55b38123a9e.pdf

Kertész, Á., Madarász, B. (2014). Conservation agriculture in Europe. International Soil and Water Conservation Research, 1, 91-96.

Komisja Europejska (2016). Rozporządzenie Parlamentu Europejskiego i Rady w sprawie rocznych wiążących ograniczeń emisji gazów cieplarnianych przez państwa członkowskie w latach 2021-2030 na rzecz stabilnej unii energetycznej i w celu wywiązania się ze zobowiązań wynikających z porozumienia paryskiego, oraz zmieniające rozporządzenie Parlamentu Europejskiego i Rady nr 525/2013 w sprawie mechanizmu monitorowania i sprawozdawczości w zakresie emisji gazów cieplarnianych oraz zgłaszania innych informacji mających znaczenie dla zmian klimatu (Regulation of the European Parliamentand of the Council on binding annual greenhouse gas emission reductions by Member States from 2021 to 2030 for a resilient Energy Union and to meet commitments under the Paris Agreement and amending Regulation No 525/2013 of the European Parliament and the Council on a mechanism for monitoring and reporting greenhouse gas emissions and other information relevant to climate change). $\operatorname{COM(2016)} 482$ wersja ostateczna.

Krasuska, E., Faber, A., Jarosz, Z., Kaczyński, R. (2016). Modelling soil organic carbon sequestration under crops for biofuels in Poland. Polish Journal of Agronomy, 27, 126-136.

Krawczynski, R., Milne, E., Banwart, S. (2015). Soil carbon, multiple benefits. Journal of Environmental Research and Development, 13, 33-38

Leip, A., Marchi, G., Koeble, R., Kempen, M., Britz, W., Li, C. (2008). Linking an economic model for European agriculture with a mechanistic model to estimate nitrogen and carbon losses from arable soils in Europe Biogeoscience, 5, 73-94.

Le Mer, J., Roger, P. (2001). Production, oxidation, emission and consumption of methane by soils: A review. European Journal of Soil Biology, 37, 25-50.

Lugato, E., Leip, A., Jones, A. (2018). Mitigation potential of soil carbon management overestimated by neglecting $\mathrm{N}_{2} \mathrm{O}$ emissions. Nature Climate Change, 8, 219-223.

Lugato, E., Bampa, F., Panagos, P., Montanarella, L., Jones, A. (2015). Potential carbon sequestration of European arable soils estimated by modelling a comprehensive set of management practices. Global Change Biology, $20,3557-3567$. 
Merante, P., Dibari, C., Ferrise, R., Bindi, M., Lesschen, P.J., Kuikman, P., Sanchez, B., Iglesias, A. (2014) Report on critical low soil organic matter contents, which jeopardise good functioning of farming systems. Smart Soil Project. Sustainable farm Management Aimed at Reducing Threats to Soils under climate change. Deliverable 2.4. Pobrano 4 marca 2018 z: http://smartsoil.eu/fileadmin/www.smartsoil.eu/Deliverables/ D2 4 SmartSoil Final.pdf.

Peltre, C., Christensen, B.T., Dragon, S., Icard, C., Kätterer, T., Houot, S. (2012). RothC simulation of carbon accumulation in soil after repeated application of widely different organic amendments. Soil Biology and Biochemistry, 52, 49-60.

Pittelkow, C.M., Linquist, B.A., Lundy, M.E., Liang, X., van Groenigen, K.J., Lee, J., van Gestel, N., Six, J., Rodney, T. Venterea, R.T., van Kessel, C. (2015). When does no-till yield more? A global meta-analysis. Field Crop Research, 183, 156-168.

Poeplau, C., Kätterer T., Bolinder M.A., Gunnar Börjesson G., Berti A., Lugato E. (2015). Low stabilization of aboveground crop residue carbon in sandy soils of Swedish long-term experiments. Geoderma, 237-238, 246-255.

Ranaivoson, L., Naudin, K., Ripoche, A., Affholder, F., Rabeharisoa, L., Corbeels, M. (2017). Agro-ecological functions of crop residues under conservation agriculture. A review. Agronomy for Sustainable Development, 37, 26.

Searle, S., Bitnere, K. (2017). Review of the impact of crop residue management on soil organic carbon in Europe. The International Council on Clean Transportation, Working Paper 2017-15. Pobrano 4 kwietnia 2018 z: https://www.theicct.org/sites/default/files/publications/EU-crop-residue-mgmt_ICCT-workingpaper_15122017_vF.pdf.

Smith, P., Martino, D., Cai, Z., Gwary, D., Janzen, H.H., Kumar, P., McCarl, B., Ogle, S., O’Mara, F., Rice, C., Scholes, R.J., Sirotenko, O., Howden, M., McAllister, T., Pan, G., Romanenkov, V., Schneider, U., Towprayoon, S., Wattenbach, M., Smith, J.U. (2008). Greenhouse gas mitigation in agriculture Philosophical Transactions of the Royal Society B, 363, 789-813.

Soane, B.D., Ball, B.C., Arvidsson, J. Basch, G., Moreno, F., Roger-Estrade, J. (2013). No-till in northern, western and southwestern Europe: a review of problems and opportunities for crop production and the environment. Soil and Tillage Research, 118, 66-87.

Stockmann, U., Adams, M.A., Crawford, J.W., Field, D.J., Henakaarchchi, N., Jenkins, M., Minasny, B., McBratney, A.B., de Remy de Courcelles, V., Singh, K., Wheeler, I., Abbott, L., Angers, D.A., Baldock, J., Bird, M., Brookes, P.C., Chenu, C., Jastrow, J.D., Lal, R., Lehmann, J., O’Donnell, A.G., Parton, W.J., Whitehead, D., Zimmermann, M. (2013). The knowns, known unknowns and unknowns of sequestration of soil organic Carbon. Agriculture, Ecosystems and Environment, 164, 80-99.

Stuczyński, T., Kozyra, J., Łopatka, A., Siebielec, G., Jadczyszyn, J., Koza, P., Doroszewski, A., Wawer, R., Nowocień, E. (2007). Przyrodnicze uwarunkowania produkcji rolniczej w Polsce. (Natural conditions of agricultural production in Poland). Studia i Raporty IUNG-PIB, 7, 1-39.

West, T.O., Six, J. (2007). Considering the influence of sequestration duration and carbon saturation on estimates of soil carbon capacity. Climatic Change, 80, 25-41. DOI: 10.1007/s10584-006-9173-8.

Wiśniewski, P., Kistowski, M. (2017). Agriculture and rural areas in the local planning of low carbon economy in light of the idea of sustainable development - results from a case study in north-central Poland. Fresenius Environmental Bulletin, 26(8), 4927-4935.

Van den Putte, A., Govers, G., Diels, J., Gillijns, K., Demuzere, M. (2010). Assessing the effect of soil tillage on crop growth: A meta-regression analysis on European crop yields under conservation agriculture. European Journal of Agronomy, 33, 231-241.

Verschuuren, J. (2018). Towards an EU regulatory framework for climate-smart agriculture: the example of soil carbon sequestration. Transnational Environmental Law, 7(2), 301-322. DOI: $10.1017 / \mathrm{S} 2047102517000395$

\section{Do cytowania / For citation:}

Faber A., Jarosz Z. (2018). Modelowanie bilansu węgla organicznego w glebie oraz emisji gazów cieplarnianych w skali regionalnej oraz w Polsce. Problemy Rolnictwa Światowego, 18(3), 102-112; DOI: $10.22630 /$ PRS.2018.18.3.70

Faber A., Jarosz Z. (2018). Modeling of Soil Organic Carbon Balance and Greenhouse Gas Emissions on a Regional Scale and in Poland (in Polish). Problems of World Agriculture, 18(3), 102-112; DOI: $10.22630 /$ PRS.2018.18.3.70 